\title{
The Idea Construction on Chinese Choice of Foreign Direct Investment under the Strategy of "One Belt One Road"
}

\author{
Yunyun Yang ${ }^{1, a}$ \\ ${ }^{1}$ Kunming University, Kunming, Yunnan, China, 650214
}

Keywords: "One Belt One Road", Foreign Direct Investment, Choice Idea

\begin{abstract}
Since the reform and opening up, Chinese economic level has increased rapidly which is mainly attributable to the success of export trade and foreign investment. In the gradual expansion of the economy at the same time, the original pattern of economic growth has shown a certain drawbacks. Economic development of the destruction of the environment, the decline in low-end manufacturing competitiveness and excess capacity and other issues has become Chinese economic development in the face of the key issues. In order to ensure the sustainable development of our economy, we must adjust its position in the international division of labor, and the choice of foreign direct investment is the key to the process of adjustment. This paper will analyze the choice of Chinese foreign direct investment under the strategy of "one way".
\end{abstract}

\section{Introduction}

In 2013, President Xi Jinping proposed to build a "one way along the way" development strategy, is the three countries with Asia, Europe and Africa together to build the "Silk Road Economic Zone" and "the 21st century Maritime Silk Road" initiative The purpose is to solve the current problems in Chinese economic development, but also reflects our participation in the world's economic cooperation in the desire. Foreign direct investment is an important way to realize the integration of the world economy. Taking the strategy of "taking all the way" as an opportunity to play our own advantages and realize the sustainable development of economy is the key research topic of our country. However, Chinese foreign direct investment has not received due attention, especially on the "one way along the country" along the country's investment options, did not conduct a comprehensive analysis and discussion, most of the investment behavior due to investment errors and serious losses. Therefore, we must analyze the choice of Chinese foreign direct investment under the strategy of "one way", and construct the correct choice.

\section{"One Belt One Road" Strategy and the Status of Chinese Export Trade}

The"One Belt One Road" Strategy. After sweeping the global financial crisis in 2008, Chinese economy has maintained a rapid growth, but rely on low-end manufacturing and government fiscal stimulus program growth has been unable to continue to support the state. Especially since the new national leaders have been in power, Chinese economy has entered a new stage of development. In order to adapt to the new economic situation and prevent the impact of the middle income trap, from the second half of 2013, China has carried out the exploration of economic transformation, the use of regional economic and financial cooperation, the use of China and neighboring countries to promote economic development. In this context, the "one way" strategy came into being. Construction of the "one way all the way" strategy is the national president $\mathrm{Xi}$ Jinping in the ASEAN and Central Asian countries to visit the proposed. Its purpose is the "Silk Road Economic Zone" and "the 21st century Maritime Silk Road" cooperation system, a comprehensive integration of the Asia-Pacific region, Central and Eastern Europe and Africa, the resources to achieve complementary advantages, the establishment of a common economic development goals. As a sponsor of this strategy, my country has actively taken a large number of follow-up actions, demonstrating the confidence to implement the strategy of "one way". In the new economic situation facing our country, the strategy of "taking all the way" is the main direction of Chinese 
future economic development. How can we improve our international status and realize the rapid economic development through this opportunity is the key issue that we need to study.

Chinese Implementation of the "One Belt One Road" Strategy. In terms of Chinese current economic development situation, with the "one side along the way" along the 65 countries and regions, has a very obvious advantage. First of all, China is the world's second largest economy, its own economic strength and population size can be for regional economic cooperation to provide relevant markets and products. Second, China currently has nearly $\$ 4$ trillion in foreign exchange reserves, which can provide the necessary financial support for investment cooperation in the region. Therefore, Chinese implementation of the "one way" strategy, the main way to build regional economic cooperation mechanism should be to increase the number of foreign direct investment, and increase the scale of export trade. From the economic point of view, Chinese increase in the number of foreign direct investment will have a certain impact on export trade, and as a key driver of economic growth, Chinese export trade will become "one way" strategy implementation of the most direct profit department.

Chinese Current Status Quo of Export Trade Scale. Since the implementation of the reform and opening up strategy, Chinese economic level has increased by leaps and bounds, the economic structure and scale have been key to the optimization and improvement. Chinese General Administration of Customs data show that in 2015, Chinese total import and export trade of goods amounted to 24.59 trillion RMB, including export trade total 14.14 trillion RMB, while the total import trade volume of 10.45 trillion RMB, trade surplus 3.69 trillion RMB. However, Chinese import and export trade volume fell by 7\% in 2015, the reason for this phenomenon is that in 2008 swept the global financial crisis, the global market demand has been in a relatively low state, and the 2015 annual RMB effective exchange rate has been in a high state. In addition, the data released by the Customs and Excise Department shows that under the current state, Chinese trade in goods exports are being adjusted, the scope of core trade partners is gradually increasing, the structure of export goods is optimized, the terms of trade have improved, trade efficiency Remarkably high.

The Problems of Chinese Export Trade. In the form of world economic integration, Chinese export of goods has made corresponding development. Over the past three decades, Chinese rapid economic growth has been largely attributable to export trade. However, at present, China has become a middle-income country. At present, the resources under the accumulation of export trade reflect the existence of many problems in Chinese economy, especially in export trade. First, Chinese economy has a high degree of dependence on export trade, resulting in the current economic structure of Chinese transformation and upgrading is facing many difficulties. Export, consumption and investment are the main source of economic development, and in the three decades of expiration, Chinese economic development is too dependent on export trade. Since the twenty-first century, Chinese total export trade will occupy more than $20 \%$ of gross domestic product, this state is undoubtedly Chinese own economic development and the global economic environment and the world political situation linked to the cause of our country Economic development has a high sensitivity to trade frictions. Traditional trade barriers, the appreciation of the RMB pressure, and all the trade frictions arising from the two are the key obstacles to Chinese export trade and economic development. Therefore, we need a timely manner on the scale of Chinese export trade to make a reasonable adjustment, the appropriate increase in domestic consumption and expand the scale of investment, strengthen the economic development of the other two main driving force. Second, Chinese export trade market is narrow and it does not have enough resistance to risk. In the current state of development, Chinese bilateral trade scale and the scale of developed countries there is still a big gap between Chinese low-end products in exports still need to rely on these developed countries, once these countries appear economic, political and cultural aspects Of the volatility of its internal market in the form of tightening will lead to the reduction of the scale of Chinese export trade, and Chinese economic development have a certain impact. In the current state, the effective increase in the number of export trade partners, increase with developing countries and emerging market countries, the scale of export trade, to achieve diversification of export trade objects is Chinese export trade development key link. 


\section{Relationship between Foreign Direct Investment and Export Trade}

Export Trade Effects of Foreign Direct Investment. In the process of foreign direct investment, if the enterprises involved in the investment is the investment countries to master the advanced science and technology enterprises. The market size of its products will be affected by the impact of the branches of the country and the investment countries to the country's export trade scale will be correspondingly reduced. This phenomenon is not only because the investment country's own cost and location there is a certain advantage, but also because of its investment in the size and technology has a certain advantage. At the same time, while the economic model continues to develop at the same time, the theme of foreign investment is gradually reducing the expected period of investment recovery, the investment in the same state of investment in the same new products and a series of practices, further increase the market of investors demand squeeze, thereby increasing the direct investment in foreign direct investment substitution effect. In addition, the brand created by foreign direct investment can also influence the consumption preference in the market through which it is invested, which is conducive to the improvement of the share of the commodity in the market of the investee.

Factors Affecting the Export Trade Effect of Foreign Direct Investment. The factors that affect the export trade effects of foreign direct investment are mainly in the following areas: first, the economic level of the investee. The level of economic development of the investee will affect the impact of foreign direct investment on the scale of export trade. The same scale of foreign direct investment, the role of developing countries in the export trade expansion is usually higher than the developed countries, the development of high countries to low levels of investment in countries and the same will stimulate the export trade. Second, it is the scale of foreign direct investment. A country's export trade is usually affected by the import market status. The development of imported economy can increase the demand for imported goods. At the same time, foreign direct investment can promote the investment industry conscious, reduce the import of goods. Therefore, the scale of foreign direct investment will affect international trade. Again, it is the motives for foreign direct investment. In order to develop overseas markets, investment countries to "colonial" foreign direct investment will be to a certain extent, occupied the market has been invested. This would have an alternative effect on export trade. Finally, it is the foreign direct investment in regional economic cooperation. In the study of foreign direct investment, it is not difficult to find that regional economic cooperation is conducive to expanding the export trade effect of foreign direct investment. For example, Chinese direct investment, the role of trade in the ASEAN countries to create greater than non-ASEAN countries, and not signed the economic cooperation agreement in the country, the investment trade to create a relatively limited role.

\section{Key Factors Affecting Chinese Choice of Foreign Direct Investment}

After a lot of research and practical verification, among the many factors, the factors that can influence the choice of foreign direct investment are mainly technical factors, market factors and strategic factors, and the impact of resource factors is not significant, this phenomenon and foreign direct investment orientation and the state of development of the investee and the geographical environment.

The Strategic Position of the Investee Is the Primary Factor in the Choice of Foreign Direct Investment. When our country is engaged in foreign direct investment in countries with "all the way along the way", if the invested countries are located in the core area along the "all the way along the way", these countries may be one of the "one way" intersection, with its own unique of the geographical advantages of its economic development will have a higher vitality in the economic development of various factors of production flow will be more frequent, Chinese direct investment in these countries will be able to play a natural advantage, you can choose to increase the Industry investment scale. At the same time, if the countries to be invested are located in the "area along the road along the expansion of the region, these countries in the economic aspects of Chinese contact is not very close, direct investment is small, its own ability to gather all kinds of 
elements and resources Limited, to its investment in the industry's leading role is not very obvious. In addition, direct investment in the "zone along the way" radiation zone will not have a significant impact on the domestic industrial structure.

Investors Market Factors Play an Active Role in the Adjustment of the Industrial Structure of the Investment Country. On the basis of seeking market investment, it can realize the adjustment of the industrial structure of the investor and the investee, which is in line with the industrial transfer of foreign direct investment. If an industry in the investment country has developed to a certain extent, after the country's demand for this industry has been met, in order to deal with the excess capacity, it needs to open up new markets, the use of foreign markets to adjust. For countries with different economic levels, the impact of foreign direct investment on the adjustment of domestic industrial structure is quite different, which shows that the investment in foreign investment industry and its own industrial demand cannot be fully matched. At the same time, the vast market of investing countries can also help the investor's products to obtain richer economic benefits, for the industry's scientific research and development to provide more adequate funds, the impact of the market will enable enterprises to more consideration The demand in the market, to enhance the product quality control and improvement of attention, continue to optimize the investment industry level.

The Technical Elements of the Investee Country Can Promote the Optimization of the Industrial Structure of the Investment Country. Learning advanced science and technology is a key factor in the progress of the developing countries to achieve great progress, if our country on the "one way" with a strong level of innovation in the country to invest directly, although there is no obvious advantage, but in order to master the advanced science and technology and innovative knowledge, basically in the form of capital for technology, close to the process of these technologies, the advanced technology to conduct a comprehensive study, imitate and master these advanced technology to promote the investment industry and economic development, the use of these advanced science and technology and new knowledge for the promotion of domestic industrial technology to promote the process of high-end industries, so the technological innovation of the country's advanced industries to direct investment, more than traditional industries can help accelerate the investment Industrial upgrading and development.

The Impact of the Resources of the Investee Country on the Industrial Structure of the Investor. If the purpose of foreign direct investment is to obtain more key natural resources, most of the investment is not a market-oriented decision, but rather want to implement the national development of the strategic orientation, this foreign direct investment and other domestic industries do not have a strong relevance, but also do not belong to the upstream and downstream relations, but also has strong volatility and chance, for example, "along the way" along the natural resource-rich countries for mineral development, oil extraction and other industries directly Investment, investment behavior itself is not a commercial investment, more focused on commerce and manufacturing.

\section{Conclusion}

All in all, foreign direct investment is a key decision on the future economic development of the country. Only by choosing the right investment country and industry can we play the real role of foreign direct investment. Therefore, under the strategy of "one way", China must carefully choose the form of foreign investment, construct reasonable investment ideas, give full play to the role of foreign direct investment in economic development, and promote the further development of the economy.

\section{References}

[1] Xu slope Ling, Liu Laihui. "One way all the way" vision of the breakthrough point of financial intermediation [J]. Journal of Xinjiang Normal University (Philosophy and Social Sciences Edition) .2016 (03) 
[2] Liu Hongzhong, Sun Yingnan. Comparison of trade expansion effects between China, Japan, Korea and ASEAN Free Trade Area - Empirical analysis based on gravity model [J]. Journal of Liaoning University (Philosophy and Social Sciences) .2015 (01)

[3] Yu Cuiping, Wang Meichang.Economic Interaction between China and "One Way Along the Road" - Empirical Analysis Based on the Perspective of GDP Spillover [J]. Asia Pacific Economic Journal (06)

[4] Li Xiao. "India's Dilemma" in the Implementation of "One Way" Strategy - The Dilemma and Countermeasures of Chinese Enterprises to Invest in India[J]. International Economic Review .2015 (05)

[5] Chen Hong, Yang Chengyu.Study on the International Economic Effect of "One Way" National Strategy - Based on the Analysis of CGE Model [J]. International Trade Issues .2015 (10)

[6] HAN Yong-hui, LUO Xiao-fei, ZOU Jian-hua.Study on Competitiveness and Complementarity of Trade Cooperation between China and West Asia - Taking "One Way" Strategy as Background [J]. World Economy Research.

[7] Jiang Guan, Huo Qiang. China-ASEAN Free Trade Area Trade Creation Effect and Trade Potential - Empirical Analysis Based on Gravity Model Panel Data [J]. Contemporary Economic Management .2015 (02) 